\title{
EFFECT OF ANTIOXIDANT SUPPLEMENTATION IN DIETS OF ROOSTERS DURING THE POST-PEAK PHASE ON REPRODUCTION AND PRODUCTION CHARACTERISTICS OF OFFSPRING
}

\author{
EFEITO DA SUPLEMENTAÇÃO DE ANTIOXIDANTES NA DIETA DE \\ REPRODUTORES DE FRANGOS DE CORTE NA FASE PÓS-PICO SOBRE \\ CARACTERÍSTICAS REPRODUTIVAS E PRODUTIVAS DA PROGÊNIE
}

\author{
Gustavo Eugenio Triques ${ }^{1}$ ORCID - http://orcid.org/0000-0002-7293-6022 \\ Adrieli Braga De Cristo ${ }^{1}$ ORCID - http://orcid.org/0000-0003-4984-4549 \\ Murício Canevese ${ }^{1}$ ORCID - http://orcid.org/0000-0001-5830-6430 \\ Patricia Fernanda dos Santos Marques ${ }^{1}$ ORCID - http://orcid.org/0000-0002-4631-4377 \\ Alvaro Mario Burin Junior ${ }^{1}$ ORCID - http://orcid.org/0000-0001-6380-0222 \\ Jovanir Ines Muller Fernandes ${ }^{1 *}$ ORCID - http://orcid.org/0000-0001-8722-7424
}

${ }^{1}$ Universidade Federal do Paraná, Palotina, PR, Brasil.

*Corresponding author - jimfernandes@ufpr.br

\begin{abstract}
This study aimed to evaluate the effects of antioxidant supplementation in diets of breeding roosters during the post-peak phase on reproduction characteristics and muscle performance of offspring in two similar breeder houses from a local company. Treatments consisted of a control diet and a diet supplemented with antioxidants ( 8 ppm canthaxanthin +40 ppm lycopene +150 ppm vitamin C). During the 66th week of age, eggs were incubated, and offspring were housed. Dietary supplementation of the blend of antioxidant resulted in higher $(\mathrm{p}<0.05)$ weights of testicles, crests, dewlaps, dewlap thickness, and number of perforations (53.35 x 25.30) in relation to non-supplemented roosters. There was no significant effect ( $p>0.05$ ) of supplementation of the antioxidant blend on weight gain and breast weight and count and diameter of muscle fibers of offspring at 7 days of age. Feed conversion and weight gain from 14 to 35 days were better $(p<0.05)$ in offspring from supplemented roosters. The supplementation of an antioxidant blend in roosters improved reproductive characteristics assessed and feed conversion and weight gain of offspring.
\end{abstract}

Keywords: antioxidant; lipid peroxidation; plasmatic membrane of sperm; muscle fibers; perivitelline membrane

\section{Resumo}

O objetivo foi avaliar o efeito da suplementação de antioxidantes em dietas para reprodutores machos de frangos de corte na fase pós-pico sobre características reprodutivas e muscular da progênie. $\mathrm{O}$ experimento foi conduzido no matrizeiro de uma agroindústria local. Os tratamentos consistiram em uma dieta controle e uma dieta suplementada com blend de antioxidantes ( $8 \mathrm{ppm}$ de cantaxantina + 40 ppm de licopeno +150 ppm de vitamina C). $\mathrm{Na}_{66^{\mathrm{a}}}$ semana de idade, os ovos foram incubados e a progênie foi alojada. A suplementação de antioxidantes na dieta resultou em maior $(p<0,05)$ peso de testículos, cristas, peso e espessura de barbelas e maior número de perfurações $(53,35$ x 25,30$)$ 
em relação aos não suplementados. Não houve efeito significativo $(p>0,05)$ dos antioxidantes na dieta dos reprodutores sobre o ganho de peso e o peso de peito e a contagem e diâmetro da fibra muscular da progênie aos 7 dias de idade. A conversão alimentar e ganho de peso na fase de 14 a 35 dias foram melhores $(\mathrm{p}<0,05)$ para a progênie dos reprodutores suplementados. A suplementação de antioxidantes na dieta dos reprodutores melhorou as características reprodutivas avaliadas e o ganho de peso e a conversão alimentar da progênie.

Palavras-chave: antioxidante, fibras musculares, membrana perivitelínica, membrana plasmática do espermatozoide, peroxidação lipídica

Received on August 31th, 2016.

Accepted on April 1st, 2019.

\section{Introduction}

Males have a fundamental role in a broiler breeder system because despite constituting only $10 \%$ of the flock in relation to females, they represent $50 \%$ of the genetic load of offspring and fertility of the flock. Breeding programs are designed to produce a broiler with high potential for growth, yield, and feed efficiency.

The plasmatic membrane of sperm differs from somatic cell membranes concerning lipid composition. The phospholipid fraction of spermatozoid membranes contains high levels of lipids such as polyunsaturated fatty acids (PUFA). These lipids are composed of non-conjugated double bonds separated by methyl groups. Wherefore becomes susceptible to oxidative damage ${ }^{(1)}$. When the levels of pro-oxidant substances such as ROS (reactive oxygen species) become high, they can attack PUFA, thereby causing a cascade of chemical reactions called lipid peroxidation (LPO).

The LPO can alter membrane structure and permeability, as well as its fluidity, and harm the melting capacity that is necessary during the acrosome reaction, consequently influencing fertility $(2,3,4)$.

Scientists studying human reproduction noted that LPO could cause infertility, abnormal embryonic development, abortions, birth defects, and childhood cancer ${ }^{(5,6,7,8)}$. Moreover, these studies indicated an important relationship between DNA damaged by LPO and implantation failures causing early neonatal mortality. González-Marín et al. ${ }^{(9)}$ also reported that $80 \%$ of aberrations in the chromosomal structure are of paternal origin.

However, few studies were conducted with animals, and among those that have been performed, a low percentage have attempted to clarify the causes of infertility in roosters of advanced age ${ }^{(10,11)}$. Aging roosters may become less interested in females and not able to complete mating, while older hens physiologically need to be mated more often in order to sustain the same level of fertility.

The effect of LPO damages on the plasmatic membrane of human sperm is known to lead to embryonic mortality and birth defects ${ }^{(8)}$. However, there is little scientific knowledge regarding male breeding.

Due to the destructive potential of ROS, spermatozoid membranes need to be protected by an effective antioxidant system that can prevent $\mathrm{LPO}^{(12)}$. The antioxidant system of semen from male breeding includes enzymes such as superoxide dismutase, glutathione peroxidase, and catalase, as well as the following natural antioxidants: vitamins A, C, and E, uric acid, glutathione, and carotenoids ${ }^{(13,14)}$. 
The association between increased lipid peroxidation and decreased fertility with age has been reported previously ${ }^{(3)}$. Thus, the use of antioxidants may contribute to mitigate the effects of oxidative stress on spermatozoa and achieve a higher fertility rate in older roosters and protect genetic material.

Carotenoids belong to an antioxidant group whose effects on LPO prevention have been widely studied $^{(15,16,17)}$. Surai and Sparks ${ }^{(15)}$ reported the importance of supplementation with carotenoids in the maternal diet on the antioxidant system (vitamins, carotenoids, and enzymes) during the embryonic development of chicks. Surai ${ }^{(18)}$ has already shown that the inclusion of canthaxanthin in maternal diets leads to a reduction in tissue susceptibility of day-old chicks to lipid peroxidation.

On the other hand, lycopene is a carotenoid without provitamin A activity, fat-soluble, and composed of eleven conjugated double bonds and two non-conjugated double bonds. It is the carotenoid that has the greatest sequestering ability for singlet oxygen possibly due to the presence of two non-conjugated double bonds that confer higher reactivity ${ }^{(19,20)}$. Lycopene supplementation in drinking water improved semen production and viability of roosters at the beginning of production ${ }^{(21)}$. Additionally, Helfenstein et al. ${ }^{(26)}$ claimed that antioxidants act together and thus the combination of antioxidants with their different profiles could lead to more effective effects on LPO.

Considering that the performance of broilers partly depends on egg quality and the diet of breeders ${ }^{(23)}$ and diets of breeders enriched with carotenoids lead to higher carotenoid concentrations in livers of first week-old chicks ${ }^{(22)}$, supplementation with carotenoids in maternal diets could represent a strategy to improve the performance of both laying hens and offspring. However, could supplementation of roosters with carotenoids lead to benefits beyond the improvement in fertility?

Helfenstein et al. ${ }^{(24)}$ supplemented male great tits (Parus major) with a blend of carotenoids and found that the supplemental dose of carotenoids enhanced male antioxidant protection and thus enabled them to produce better sperm with higher competitive ability, leading to higher paternity and better offspring quality. According to the authors, any effect of carotenoids on antioxidant protection of sperm must be indirect, via a contribution to the overall antioxidant system, ultimately reducing oxidative stress in the testes.

Additionally, carotenoids may improve male health status and condition during breeding and enhance its attractiveness through, for example, a higher investment into mating activities. The differential allocation hypothesis predicts that females should invest more in reproduction when mated to more attractive partners ${ }^{(25)}$.

This study aimed to evaluate the effects of the dietary inclusion of antioxidants to roosters above 50 weeks of age on reproduction parameters and production and muscular performance of offspring.

\section{Material and methods}

For all animal raising and biological material collection, procedures were approved by the Ethics Committee on Animal Use in Research (no. 29/2012).

The experiment was performed at the facilities from a local company with 4 breeder houses, each one composed by 9,000 Cobb Slow breeders and 1,000 roosters at 50 weeks of age. In two out of the four barns, roosters received specific commercial diet for males (control diet), while in the other two, roosters received a diet supplemented with antioxidants (supplemented diet). 
The control diet was a commercial feed, while the supplemented diet consisted of a commercial feed +8 ppm canthaxanthin (Carophyll Red 10\%; DSM Nutritional Products) + Lycopene 40 ppm (Lycopene 10\%; Roche Vitamins) + 150 ppm Vitamin C (Rovimix C-EC 97.5\%; DSM Nutritional Products).

A corn and soy meal-based diet, formulated according to the nutritional demands of post-peak production roosters ${ }^{(27)}$, were used. During the experiment, diets were supplied daily $(8 \mathrm{AM})$, as recommended by the Cobb lineage manual ( $150 \mathrm{~g} /$ rooster/day). The breeder barn had thermostatically controlled environment in order to keep the temperature at $23 \pm 2{ }^{\circ} \mathrm{C}$ and relative humidity at $61 \pm 10 \%$.

At 62 weeks of age, 60 eggs/treatment were collected and assessed for perforations of the vitelline membrane. According to the technique described by Bramwell et al. ${ }^{(28)}$, a cut of $1 \mathrm{~cm}^{2}$ was performed around the germinative disk, and then, successive washings with a saline solution were carried out to remove the yolk and albumen. After placing it on a glass slide, the membrane was fixed using formaldehyde and stained with acid-Schiff-reactive for further analysis on perforations of the vitelline membrane through the optical microscope technique (40X objective).

After 18 weeks of supplementation, 12 roosters/treatment were weighed and then euthanized following the procedure of CONCEA (National Council of Animal Experimentation Control) guidelines for experimental animals, as follows: after physical restraint, a catheter no. 22 was fixed in the femoral vein for propofol (Propovan $10 \mathrm{mg} / \mathrm{mL}$, Cristália Laboratory) infusion in the bolus until unconsciousness. Subsequently, 19.1\% potassium chloride (Isofarma Laboratory) was immediately administered by the same route until the confirmation of death. Next, combs and dewlaps of all roosters were evaluated (weight, length, and thickness). The breast and right test were removed from the carcass, weighed and measured.

At 66 weeks of age, two weeks before rooster slaughtering, eggs from the 4 barns were collected, identified, and sent to the hatchery of the same local company. After hatching, 288 1-day-old male chicks were housed following a randomized design with 2 treatments and 6 replications containing 24 birds each pen. Treatments were: A - offspring from roosters fed commercial feed and B - offspring from roosters fed commercial feed and supplemented with an antioxidant blend. Food and water were allowed ad libitum during the entire experimental period. The nutritional program was split into two phases, starter (1-21 days) and growing (22-35 days). Corn-soybean meal-based diets were formulated following the chemical composition of ingredients, as well as the nutritional recommendations from local companies, in a feeding programming divided into two phases (initial: $23.00 \% \mathrm{CP}, 3,100 \mathrm{ME}$ $\mathrm{kcal} / \mathrm{kg}, 1.250 \%$ Lys, and growing: $21.25 \% \mathrm{CP}, 3,200 \mathrm{ME} \mathrm{kcal} / \mathrm{kg}, 1.160 \% \mathrm{Lys})$. During the trial, the average weight of birds, feed intake, and feed conversion ratio was assessed at 7, 14, and 35 days of age.

Four birds per replication were sacrificed (24/treatment) at day 7 through cervical dislocation. The eviscerated carcass and breast were weighted, and samples of the superficial part of the Pectoralis major muscle was collected. After cleaning and fragmentation to approximately $1 \mathrm{~cm} \mathrm{X} 0.5 \mathrm{~cm}$, the samples were labeled, frozen, and stored in liquid nitrogen containers until processing. Muscle fragments were transferred to a cryostat chamber with embedding medium for frozen tissue specimens to ensure (Sakura Finetek Europe B.V., Netherlands) processing. Fiber sample cross-sections of about $8 \mu \mathrm{m}$ thick were stained with hematoxylin-eosin for general tissue morphological evaluation and measurement of fiber diameter. In the morphometric study, images were captured using a light microscope (Olympus Bx 40, Artisan Scientific Corporation, Champaign, IL) and a system that analyzes computerized images (IMAGE PROPLUS 5.2 from Media Cybertechnics, São Paulo, Brazil). Ten muscle tissue images were captured for each evaluated bird with final magnification 
equivalent to a $10 \mathrm{X}$ eyepiece and a $10 \mathrm{X}$ objective. Twenty myofibers, totaling 200 myofibers per bird (2400 fibers/treatment) were measured in each image by the least diameter method, according to Dubowitz ${ }^{(29)}$.

Carcass yield was determined in two birds at random per experimental unit at 35 days. The birds were identified and fasted for $6 \mathrm{~h}$ and euthanized by electric stunning and bleeding.

Carcass yield was calculated as the ratio of hot eviscerated carcass and body weight before euthanasia. Prime cut yield (whole breast, thigh, and legs, all with skin and bones) was calculated in relation to the weight of the eviscerated carcass.

Abdominal fat around the cloaca in the bursa of Fabricius, gizzards, proventriculus, and adjacent abdominal muscles was removed ${ }^{(30)}$. Subsequently, the carcass was weighed, and carcass yield was calculated in relation to the eviscerated carcass.

Preliminary data analyses were performed to check for outliers and ensure no violation of assumptions of normality (Cramer Von Mises test) and homogeneity of variance (Brown-Forsythe test). The data were then subjected to analysis of variance (ANOVA) by the GLM procedure of the software SAS (SAS INSTITUTE, 2002).

\section{Results}

The weight of testicles, combs, and dewlaps, as well as dewlap thickness, were higher $(\mathrm{p}<0.05)$ in roosters supplemented with the antioxidant blend (Table 1).

Table 1. Morphometric measurements of tests, dewlap, and comb of roosters supplemented or not with an antioxidant blend, from 50 to 68 weeks of age

\begin{tabular}{lccc}
\hline & \multicolumn{3}{c}{ Tests } \\
\cline { 2 - 4 } Control & Weight, $\mathbf{g}$ & Length, cm & Thickness, cm \\
Antioxidant blend & $11.20^{\mathrm{b}}$ & 2.22 & 1.23 \\
CV, \% & $17.19^{\mathrm{a}}$ & 3.53 & 1.74 \\
P-value & 42.34 & 35.50 & 33.98 \\
& 0.0484 & 0.2310 & 0.1107 \\
\cline { 2 - 4 } Control & Deight $(\mathrm{g})$ & Length $(\mathrm{cm})$ & Thickness (mm) \\
Antioxidant blend & $9.13^{\mathrm{b}}$ & 6.38 & $3.59^{\mathrm{b}}$ \\
CV, \% & $16.26^{\mathrm{a}}$ & 5.28 & $4.96^{\mathrm{a}}$ \\
P-value & 24.56 & 14.78 & 21.32 \\
\hline & 0.0296 & 0.0516 & 0.0261 \\
\cline { 2 - 4 } & \multicolumn{3}{c}{ Comb } \\
Control & Weight (g) & Length $(\mathrm{cm})$ & Thickness (mm) \\
Antioxidant blend & $18.57^{\mathrm{b}}$ & 5.48 & 10.55 \\
CV, \% & $30.37^{\mathrm{a}}$ & 6.72 & 10.90 \\
P-value & 18.98 & 19.48 & 10.56 \\
\hline
\end{tabular}

Different lowercase letters in the same column differ significantly ( $p<0.05$ ). 
Table 2 shows that roosters supplemented with the antioxidant blend presented higher body weights and higher ratios between testicle weight and body weight than roosters without supplementation. The percentage of the breast in relation to weight of roosters was not affected by antioxidant supplementation $(\mathrm{p}>0.05)$.

Table 2. Live weight of breast and testicle yield and count of the number of vitelline membrane sperm holes of eggs from breeders mated with roosters supplemented or not with an antioxidant blend, from 50 to 68 weeks of age

\begin{tabular}{lcccc}
\hline & Live weight, $\mathbf{~ k g}$ & Breast, \% & Test, \% & Number of holes \\
\cline { 2 - 5 } Control & $3.84^{\mathrm{b}}$ & 21.48 & $0.17^{\mathrm{b}}$ & $25.30^{\mathrm{b}}$ \\
Antioxidant blend & $4.69^{\mathrm{a}}$ & 22.68 & $0.35^{\mathrm{a}}$ & $53.35^{\mathrm{a}}$ \\
CV, \% & 13.51 & 17.98 & 34.56 & 46.63 \\
P-value & 0.0478 & 0.6377 & 0.0223 & 0.0110 \\
\hline
\end{tabular}

Different lowercase letters in the same column differ significantly $(\mathrm{p}<0.05)$.

Regarding the number of spermatic holes through the vitelline membrane, which consists of the microscopic evaluation of the perivitelline membrane that covers the germinal disk, thereby verifying spermatic holes through the first structure, eggs from supplemented roosters showed a higher number $(\mathrm{p}<0.05)$ in comparison to the control.

Production performance results of offspring are shown in Table 3. A significant positive effect $(p<0.05)$ of the inclusion of antioxidants in the diet of roosters was observed on live weight, weight gain, and feed conversion from 14 to 35 days.

Table 3. Offspring performance from roosters supplemented or not with an antioxidant blend, from 50 to 68 weeks of age

\begin{tabular}{lcccc}
\hline & Live weight, g & Weight Gain, g & Feed Intake, g & Feed Conversion \\
\hline & \multicolumn{5}{c}{ 1-7 days of age } \\
\cline { 2 - 5 } Control & 203.75 & 154.99 & 176.18 & 1.140 \\
Antioxidants & 205.67 & 152.81 & 172.72 & 1.130 \\
Mean & 204.71 & 153.90 & 174.45 & 1.134 \\
CV, \% & 2.89 & 3.44 & 5.53 & 4.92 \\
P-value & 0.4456 & 0.4912 & 0.5487 & 0.8676 \\
\hline & \multicolumn{4}{c}{$1-14$ days of age } \\
Control & 460.81 & 361.08 & 490.92 & 1.363 \\
Antioxidants & 456.42 & 361.83 & 486.62 & 1.352 \\
Mean & 458.61 & 361.46 & 488.77 & 1.358 \\
CV, \% & 6.67 & 7.45 & 4.03 & 8.57 \\
P-value & 0.5543 & 0.5280 & 0.7133 & 0.8543 \\
\hline & \multicolumn{2}{c}{$1-35$ days of age } \\
Control & $1646.67^{\mathrm{b}}$ & $1595.73^{\mathrm{b}}$ & 2456.40 & $1.550^{\mathrm{a}}$ \\
Antioxidants & $1724.59^{\mathrm{a}}$ & $1673.91^{\mathrm{a}}$ & 2405.69 & $1.450^{\mathrm{b}}$ \\
Mean & 1685.63 & 1634.82 & 2431.04 & 1.500 \\
CV, \% & 4.89 & 6.55 & 7.97 & 12.45 \\
P-value & 0.0046 & 0.0575 & 0.5280 & 0.0207 \\
\hline
\end{tabular}

Different lowercase letters in the same column differ significantly $(\mathrm{p}<0.05)$. 
In the evaluation of muscle development at 7 days (Table 4), the number and diameter of muscle fibers were measured, as well as the breast weight and yield. No significant differences $(p>0.05)$ were observed between treatment and control groups.

Table 4. Assessment of muscle development of 7-day-old progeny from roosters supplemented or not with an antioxidant blend, from 50 to 68 weeks of age

\begin{tabular}{lcccc}
\hline & Breast, $\mathbf{g}$ & Breast, $\%$ & $\begin{array}{c}\text { Number of } \\
\text { muscle fibers }\end{array}$ & $\begin{array}{c}\text { Diameter of } \\
\text { muscle fibers, } \boldsymbol{\mu m}\end{array}$ \\
\cline { 2 - 5 } & & & $1-7$ days of age \\
Control & 32.79 & 15.73 & 126.87 & 77.06 \\
Antioxidants & 31.05 & 15.48 & 124.28 & 76.43 \\
Mean & 31.94 & 15.61 & 125.66 & 76.78 \\
CV, \% & 9.45 & 5.66 & 11.48 & 10.86 \\
P-value & 0.1741 & 0.3306 & 0.6284 & 0.8381 \\
\hline
\end{tabular}

Table 5 shows the carcass yield results at 35 days of offspring of roosters supplemented or not with antioxidants during their post-peak stage. No effect of any treatment ( $p>0.05)$ was observed for these characteristics.

Table 5. Carcass yield at 35 days of the age of progeny from roosters supplemented or not with an antioxidant blend, from 50 to 68 weeks of age

\begin{tabular}{lcccccc}
\hline & Carcass, g & Carcass, \% & Breast, g & Breast, \% & Legs, g & Legs, \% \\
\cline { 2 - 7 } Control & 1645.17 & 73.31 & 608.50 & 36.95 & 461.08 & 28.06 \\
Antioxidants & 1646.08 & 73.06 & 619.33 & 37.62 & 449.75 & 27.35 \\
Mean & 1645.63 & 73.18 & 613.92 & 37.29 & 455.42 & 27.71 \\
CV, \% & 6.03 & 5.36 & 8.71 & 5.36 & 5.88 & 4.63 \\
P-value & 0.9746 & 0.8260 & 0.4866 & 0.2529 & 0.1496 & 0.079 \\
\hline
\end{tabular}

\section{Discussion}

Several studies attempt to relate secondary sexual characteristics of roosters to their fertility. McGary et al. ${ }^{(31)}$ reported that testicle weight is directly associated with daily spermatic production and the fertility rate of the flock. McGary et al. ${ }^{(32)}$, when relating secondary sexual characteristics to factors such as fertility, testicle weight, and penetration of sperm through the perivitelline membrane, concluded that there is a positive correlation between testicle weight and comb area, as well as comb height and dewlap length with penetration of sperm through the perivitelline membrane.

Hanafy et al. ${ }^{(33)}$ supplemented broiler breeder male diets with 0 to $0.3 \mathrm{mg}$ selenomethionine per $\mathrm{kg}$ and observed higher semen quality, resulting in higher fertility and hatchability. Semen is rich in PUFA, which are required to maintain sperm membrane properties but are highly susceptible to peroxidation ${ }^{(34)}$. The defense system that includes antioxidants, such as tocopherols, flavonoids, carotenoids, ascorbic acid, and selenium could reduce its susceptibility to oxidation and, consequently, increase fertility.

Lipid peroxidation is one of the main causes of damage to spermatic morphology, which can influence 
spermatozoid motility and penetration of the perivitelline membrane, compromising fertility of the flock.

Spermatozoid should be able to penetrate the perivitelline membrane to fertilize the ova ${ }^{(35)}$. Supplementation with antioxidants has resulted in a higher number of holes in the perivitelline membrane. The inner perivitelline may be penetrated by many sperms, although only one male pronucleus will ultimately fuse with the female pronucleus to form the embryo ${ }^{(36,37)}$. On the other hand, a single sperm hole in the inner perivitelline does not ensure fertilization. Birds are known to be poly-spermatic, and a single egg can contain hundreds of perforations.

The perforations, according to Waclawek et al. ${ }^{(38)}$, are hydrolysate holes whereby sperm penetrated the oocyte. Perforations in the vitelline membrane are caused by the release of enzymes by sperm in order to hydrolyze the membrane and reach the nucleus.

The number of holes in the inner perivitelline is highly positively correlated with fertility. Correlations exist between the number of sperm inseminated, the number undergoing the acrosome reaction at the inner perivitelline, and the number of sperm embedded in the outer perivitelline ${ }^{(39,37)}$. The number of sperm holes in the inner perivitelline and the number of sperm trapped in the outer perivitelline may be used to estimate the duration of fertility ('fertile period') in hens ${ }^{(40,41,42,37)}$ and, in an indirect way, to evaluate the reproductive performance of roosters ${ }^{(28)}$.

The results suggest that adding antioxidants to the diets of roosters can increase the production of sperm or lead to better quality sperm with higher survival conditions in order to reach the infundibulum soon after ovulation.

Murakami et al. ${ }^{(43)}$ did not observe differences in the number of sperm in the vitelline membrane of fertile eggs resulting from breedings (laying hen and rooster) when roosters were supplemented with vitamin E. However, the diets of laying hens were also supplemented, and it can have a strong influence on the results. Zhang et al. ${ }^{(44)}$ reported that canthaxanthin supplementation of the maternal diet resulted in an enhancement of the serum total antioxidant capacity of breeder hens and newly hatched chicks. Rosa et al. ${ }^{(45)}$ also found that the supplementation of broiler breeder diets with canthaxanthin reduced the presence of thiobarbituric reactive substances in eggs.

The effects of antioxidant supplementation in diets of roosters on offspring are not often studied, and the productive performance characteristics of offspring rely more on roosters than laying hens, which would justify a better offspring performance when they are descended from roosters with better seminal quality ${ }^{(46)}$.

Male great tits do not courtship-feed their mate ${ }^{(47)}$ and are thus unlikely to influence egg quality directly. As females mated to both types of males laid clutches of similar mass, their eggs must have differed in their composition. Helfenstein et al. ${ }^{(26)}$ emphasize that females may have deposited different amounts of nutrients, such as lipids, antioxidants, carotenoids, and vitamins A and E, or hormones into the eggs. These results are in accordance with the differential allocation hypothesis ${ }^{(48)}$, which proposes that females should adjust their reproductive investment to male attractiveness.

Females not only laid eggs that produced better offspring quality but also granted more paternity to their mates. If supplementary carotenoids affected mate-guarding behavior, males might have been better able to secure their paternity. However, female birds have been shown to retain most of the control over copulation and fertilization ${ }^{(49)}$, and paternity assurance strategies are generally regarded as the best-of-a-bad-job ${ }^{(26)}$. Thus, the higher paternity achieved by carotenoid-supplemented males is likely to reflect female fertilization strategies. 
Carotenoid-supplemented males produced better sperm quality. Vertebrate sperm shows high rates of metabolic activity and free radical production and is rich in polyunsaturated fatty acids, which makes them particularly susceptible to oxidative stress ${ }^{(34,1)}$ that lead to extensive cellular damage ${ }^{(50)}$. Sperm also contains highly condensed nucleic DNA and reduced cytoplasm resulting in DNA damage that is more likely to accumulate without repair ${ }^{(5,6,7,8)}$. These oxidative damages to sperm membranes and sperm DNA can lead to increased infertility, offspring of lower quality ${ }^{(9)}$, and reduced sperm swimming ability, a prominent parameter of sperm competitive ability ${ }^{(27)}$. The supplemental dose of carotenoids may have enhanced the antioxidant protection of males and thus enabled them to produce better sperm with higher competitive ability, leading to higher paternity and better offspring quality.

Selection for increased growth and yield of commercial broiler has taken place at the expense of reproductive performance in broiler breeder parents. However, in this experiment, no differences were observed in production performance, muscle development, or carcass yield of offspring.

Barreto et al. ${ }^{(51)}$, when evaluating levels of vitamin $\mathrm{E}$ in diets of breeding laying hens, concluded that offspring presents better performance when laying hens receive supplementation of this vitamin. The benefits of maternally derived antioxidants in the developing embryo do not terminate at hatch, but instead, are retained to varying extents in the offspring tissues throughout the early stages of growth ${ }^{(15}$, 19,52).

Also, hatchlings derived from broiler breeders fed diets containing organic selenium were heavier ${ }^{(53)}$. However, both females and males were supplemented, which did not allow concluding whether the main effect was obtained from female or male.

In future studies, the evaluation of the total antioxidant capacity and TBA reactive species (TBARS) content of seminal plasma could be measured to correlate oxidative damage in spermatozoa with progeny performance and health. Studies with humans demonstrated that the oxidative stress not only disrupts the integrity of sperm DNA but also may increase the potential to create a mutation and could account for the range of pathologies seen in the offspring of fathers exhibiting high levels of oxidative DNA damage in their spermatozoa ${ }^{(54)}$.

Besides that, recent studies on epigenetics in male reproduction were reviewed by Schagdarsurengin and Steger ${ }^{(55)}$. These studies provide evidence that the influence of environmental and nutritional factors on offspring health is not restricted to the female, but it is shared by the male, as sperm-specific epigenetic signatures ('cellular memory') are transferred to the oocyte and can, therefore, affect embryo development and offspring health. These data suggest that these factors affect addition or removal of chemical tags to or from DNA or histones and that these epigenetic signatures are heritable and able to switch genes on or off in the offspring. However, the knowledge of transgenerational epigenetics in production animals is still sparse.

\section{Conclusion}

Supplementation with an antioxidant blend composed of canthaxanthin, vitamin C, and lycopene in roosters led to higher testicles, combs, and dewlaps.

A higher number of spermatic perforations was observed in the perivitelline membrane of fertilized eggs of supplemented roosters.

The supplementation of an antioxidant blend in roosters did not improve production performance, 
muscle development, and carcass yield of their offspring.

\section{Acknowledgments}

The researches would like to thank DSM Nutritional Products for providing the antioxidants.

\section{References}

1. Makker K, Agarwal A, Sharma R. Oxidative stress and male infertility. The Indian Journal of Medical Research. 2009;129(4):357-367.

2. Ferreira ALA, Matsubara LS. Radicais livres: conceitos, doenças relacionadas, sistema de defesa e estresse oxidativo. Revista da Associação Médica Brasileira. 1997;43(1):61-68.

3. Shanmugam, M., Vinoth, A., Rajaravindra, K.S., Rajkumar, U. Evaluation of semen quality in roosters of different age during hot climatic condition. Animal Reproduction Science 2014; 145(1):81-85.

4. Khan R. Antioxidants and poultry semen quality. World's Poultry Science Journal. 2011; 67(2), 297-308.

5. Agarwal A, Gupta S, Sikka S. The role of free radicals and antioxidants in reproduction. Current Opinion in Obstetrics and Gynecology. 2006;18(3):325-332.

6. Agarwal A, Makker K, Sharma R. Clinical relevance of oxidative stress in male factor infertility. American Journal of Reproductive Immunology. 2008;59(1):2-11.

7. Tremellen K. Oxidative stress and male infertility--a clinical perspective. Human Reprodiction Update. 2008;14(3):243-58.

8. Agarwal A, Virk G, Ong C, du Plessis SS. Effect of Oxidative Stress on Male Reproduction. World J Mens Health. 2014;32(1):1-17.

9. González-Marín C, Gosálvez J, Roy R. Types, causes, detection and repair of DNA fragmentation in animal and human sperm cells. International Journal of Molecular Sciences. 2012;13(11):14026-14052.

10. Long JA, Kramer M. Effect of vitamin E on lipid peroxidation and fertility after artificial insemination with liquid-stored Turkey semen. Poultry Science. 2003;82(11):1802-1807.

11. Fragoso JS, Díaz MP, Moreno JA, Infesta PC, Bertos AR, Barger K. Relationships Between Fertility and Some Parameters in Male Broiler Breeders (Body and Testicular Weight, Histology and Immunohistochemistry of Testes, Spermatogenesis and Hormonal Levels). Reproduction in Domestic Animal. 2013;48(2): 345-352.

12. Hammadeh ME, Filippos A, Hamad MF. Reactive oxygen species and antioxidant in seminal plasma and their impact on male fertility. International Journal of Fertility and Sterility. 2009;3(3): 87-110.

13. Cerolini S, Zainiboni L, Maldjian A, Gliozzi T. Effect of docosahexaenoic acid and $\alpha$-tocopherol enrichment in chicken sperm on semen quality, sperm lipid composition and susceptibility to peroxidation. Theriogenology. 2006;66(4):877-886.

14. Partyka A, Łukaszewicz E, Niżański W. Lipid peroxidation and antioxidant enzymes activity in avian semen. Animal Reproduction Science. 2012;134:184-190.

15. Surai PF, Sparks NH. Comparative evaluation of the effect of two maternal diets on fatty acids, vitamin E 
and carotenoids in the chick embryo. British Poultry Science. 2001;42(2):252-259.

16. Moller AP, Biard C, Blount JD, Houston DC, Ninni P, Saino N, Surai PF. Carotenoid-dependent signals: indicators of foraging efficiency, immunocompetence or detoxification ability? Avian and Poultry Biology Reviews. 2000;11(3):137-159.

17. Bansal AK, Bilaspuri GS. Impacts of oxidative stress and antioxidants on semen functions. Veterinary Medicine International. 2011; 2011: 1-7.

18. Surai PF. Effect of canthaxanthin contente of the maternal diet on the antioxidant system of the developing chick. British Poultry Science. 2003;44(4):612-619.

19. Di Mascio P, Kaiser S, Sies S. Lycopene as the most efficient biological carotenoid singlet oxygen quencher. Archives of biochemistry and biophysics. 1989;274(2):532-538.

20. Agarwal S, Rao AV. Tomato lycopene and its role in human health and chronic diseases. . Canadian Medical Association or its licensors. 2000;163(6):739-744.

21. Mangiagalli MG, Martino PA, Smajlovic T, Guidobono Cavalchini L, Marelli SP. Effect of lycopene on semen quality, fertility and native immunity of broiler breeder. British Poultry Science. 2010;51(1):152-157.

22. Karadas F, Pappas AC, Surai PF, Speake BK. Embryonic development within carotenoid-enriched eggs influences the post-hatch carotenoid status of the chicken. Comparative Biochemistry and Physiology B: Biochemistry and Molecular Biology. 2005;141(2):244-251.

23. Paton ND, Cantor AH, Pescatore AJ, Ford MJ, Smith CA. The effect of dietary selenium source and level on the uptake of selenium by developing chick embryos. Poultry Science. 2002;81(10):1548-1554.

24. Helfenstein F, Losdat S, Saladin V, Richner H. Females of carotenoid-supplemented males are more faithful and produce higher quality offspring. Behavioral Ecology. 2008;19(6):1165-1172.

25. Velando A, Beamonte-Barrientos R, Torres R. Pigment-based skin colour in the blue-footed booby: an honest signal of current condition used by females to adjust reproductive investment. Oecologia. 2006;149:535-542.

26. Helfenstein F, Losdat S, Møller AP, Blount JD, Richner H. Sperm of colourful males are better protected against oxidative stress. Ecology Letters. 2010;13(2):213-222.

27. COBB VANTRESS. Guia de manejo de matrizes COBB. Guapiaçu: Cobb Vantress Brasil; 2013. 57p. Portuguese.

28. Bramwell RK, Howarth BJr. Preferential attachment of cock spermatozoa to the perivitelline layer directly over the germinal disc of the hen's ovum. Biology of Reproduction.1992; 47(6):1113-1117.

29. Dubowitz V. Muscle Biopsy: A Practical Approach. 2nd ed. London: Bailliere Tindall; 1985. 719p.

30. Smith MO. Parts yield of broilers researed under cycling high temperatures. Poultry Science. 1993; 72(6):1146-1150.

31. Mcgary S, Estevez I, Bakst MR. Phenotypic traits as reliable indicators of fertility in male broiler breeders. Poultry Science. 2002;81(1):102-111.

32. Mcgary S, Estevez I, Ottinger MA. Can testosterone and corticosterone predicted the rate of display of male sexual behavior, development of secondary characters and fertility potential in primary broiler breeders? British Poultry Science. 2005;46(5):621-625.

33. Hanafy MM, El-Sheik AMH, Abdalla EA. The effect of organic selenium supplementation on productive and 
physiological performance in local strain of chicken. Egyptian Poultry Science Association. 2009;29(4):10611084.

34. Surai PF, Ionov IA, Kuchmistova EF, Noble RC, Speake BK. The relationship between the levels of $\alpha$-tocopherol and carotenoids in the maternal feed, yolk and neonatal tissues: comparison between the chicken, turkey, duck and goose. Journal of the Science of Food and Agriculture. 1998;76(4):593-598.

35. Rutz F, Anciutti MA, Xavier EG, Roll VFB, Rossi P. Avanços na fisiologia e desempenho reprodutivo de aves domésticas. Revista Brasileira de Reprodução Animal. 2007;31(3):307-317.

36. Stepinska U, Bakst MR. Fertilization. In: Jamieson BGM. Reproductive Biology and Phylogeny of Birds. Enfield, New Hampshire: Science Publishers; 2007. p. 87-553.

37. Sasanami T, Murata T, Ohtsuki M, Matsushima K, Hiyama G, Kansaku N and Mori M. Induction of sperm acrosome reaction by perivitelline membrane glycoprotein ZP1 in Japanese quail (Coturnix japonica). Reproduction. 2007; 133(1): 41-49.

38. Waclawek M, Foisner R, Nimpf J, Schneider WJ. The chicken homologue of zona pellucida protein-3 is synthesized by granulosa cells. Biology of Reproduction. 1998;59(5):1230-1239.

39. Wishart GJ. Regulation of the length of the fertile period in the domestic fowl by numbers of oviducal spermatozoa, as reflected by those trapped in laid eggs. Journal of Reproduction and Fertility. 1987;80(2):493498.

40. Robertson L, Wilson YI, Lindsay C, Wishart GJ. Evaluation of semen from individual male domestic fowl by assessment of sperm: periviteline interaction in vitro and in vivo. British Poultry Science. 1998; 39(2): 278-281.

41. Christensen VL, Fairchild BD. The relationship between sperm hydrolysis of the periviteline layer and embryonic livability. The Journal of Applied Poultry Research. 2005;14(1):60-68.

42. Malgorzata G, Kapkowska A. Age effect of broiler breeders on fertility and sperm penetration of the perivitelline layer of the ovum. Animal Reproduction Science. 2005;90(1-2):135-148.

43. Murakami AE, Santos TC, Fernandes JIM, Bortoluzzi C, Martinez AC. Desempenho produtivo e reprodutivo de matrizes de frangos de corte com dietas suplementadas com vitamina E, óleo de soja e óleo de peixe. Revista Brasileira de Reprodução Animal. 2013; 37(3):285-294.

44. Zhang W, Zhang KY, Ding XM, Bai SP, Hernandez JM, Yao B, Zhu, Q. Influence of canthaxanthin on broiler breeder reproduction, chick quality, and performance. Poultry Science. 2011;90(7):1516-22.

45. Rosa P, Scher A, Sorbara JOB, Boemo LS, Forgiarini J, Londero A. Effects of canthaxanthin on the productive and reproductive performance of broiler breeders. Poultry Science. 2012; 91(3): 660-666.

46. Chang A, Halley J, Silva M. Can feeding the broiler breeder improve chick quality and offspring performance? Animal Production Science. 2016; 56 (8):1254-1262.

47. Walker, G. Role of male great tit in nest-building. British Birds. 1977;70:123.

48. Burley NT. The differential-allocation hypothesis: an experimental test. The American Naturalist. 1998;132(5):611-628.

49. Cunningham E, Birkhead T. Female roles in perspective.Trends in ecology \& evolution. 1997; 12(9):337338.

50. Twigg J, Fulton N, Gomez E, Irvine DS, Aitken RJ. Analysis of the impact of intracellular reactive oxygen 
species generation on the structural and functional integrity of human spermatozoa: lipid peroxidation, DNA fragmentation and effectiveness of antioxidants. Human Reproduction. 1998;13(6):1429-1436.

51. Barreto SLT, Hossain SM, Mourão GB. Níveis de vitamina E na dieta e desempenho produtivo e reprodutivo de reprodutoras de frango de corte. Arquivo Brasileiro de Medicina Veterinária e Zootecnia. 1997;49(4):453463.

52. Pappas ACF, Karadas PF, Speake BK. The selenium intake of the female chicken influences the selenium status of her progeny. Comparative Biochemistry and Physiology B: Biochemistry and Molecular Biology. 2005; 142(4):465-474.

53. Urso URA, Dahlke F, Maiorka A, Bueno IJM, Schneider AF, Surek D, Rocha C. Vitamin E and selenium in broiler breeder diets: Effect on live performance, hatching process, and chick quality. Poultry Science. 2015;94(5):976-983.

54. Aitken RJ, Smith TB, Jobling MS, Baker MA, De Iuliis GN. Oxidative stress and male reproductive health. Asian Journal of Andrology. 2014;16(1):31-38.

55. Schagdarsurengin U, Steger K. Epigenetics in male reproduction: effect of paternal diet on sperm quality and offspring health. Nature Reviews Urology. 2016;13(10):584-595. 